\title{
The Dissociative Experiences Scale: A Welsh Translation
}

\section{Christopher Alan Lewis, Martin J. Dorahy, Julie Brake, Mary Jane Lewis}

Dear Editor,

For both researchers and clinicians there exists a wide range of self-report instruments to measure frequency and types of dissociative experience. Examples include the Perceptual Alterations Scale, ${ }^{1}$ the Questionnaire of Experiences of Dissociation, ${ }^{2}$ the Dissociation Questionnaire, ${ }^{3}$ the Dissociative Processes Scale, ${ }^{4}$ the Multiscale Dissociation Inventory, ${ }^{5}$ and the Child Dissociative Checklist. ${ }^{6}$

The Dissociative Experiences Scale (DES), ${ }^{7}$ a $28-$ item instrument that measures a wide variety of dissociative phenomena (e.g., absorption, imaginative involvement, depersonalisation, derealisation, amnesia), is the most frequently used. ${ }^{8}$ In addition to the original DES, there now exists a wide range of adaptations of the measure for use among specific samples, including adolescents, ${ }^{9}$ the visually impaired, ${ }^{10}$ and the profoundly deaf. ${ }^{11}$ Moreover, there are a large number of foreign language translations of the DES.12 Examples include translations into Dutch, ${ }^{13}$ Turkish, ${ }^{14}$ Japanese, ${ }^{15}$ German, ${ }^{16}$ French, ${ }^{17}$ Hebrew, ${ }^{18}$ Finnish, ${ }^{19}$ and Portuguese. ${ }^{20}$

The present aim was to provide a Welsh translation of the DES for use among Welsh speakers. The utility of such a tool is that it should help facilitate the work of clinicians and researchers in Wales. For clinicians, the availability of such a tool would allow assessment of dissociative experiences and symptoms among service users who prefer to be assessed in Welsh. At present, outside of the GP practice most "health-related business" is conducted in English. 21,22,23,24,25 For researchers, the availability of the tool would mean that dissociation, and potentially its antecedents and correlates, could be examined using language sensitive measures, thus heightening the ecological validity of work in this area

The DES was translated and back translated by two experienced translators familiar with health-related research. No relevant cultural differences were found for any item. This is not surprising given that the events and activities which evoke, anchor to, or are associated with dissociation in the North American context from which items were written do not differ from those of Welsh speakers in Wales. Linguistically, only item 8 proved a little problematic in translation. This is because the impersonal "some people are told" in Welsh is quite formal (linguistic registers in Welsh are more obvious than in English) and there is a tendency to use active rather than passive constructs. "Some people find" also could not be translated directly as this idiom is not used in Welsh. Appendix 1 contains the 28 items of the Welsh translation of the DES.

Further work is now required to examine the reliability and validity of the Welsh translation of the DES. Initial research should focus on establishing the psychometric properties of the scale, including examining the internal reliability, temporal stability, convergent validity, and construct validity. Providing the scale was found to be reliable and valid, subsequent research may wish to establish the correlates and antecedents of dissociation within the Welsh context. It is hoped that the present contribution helps stimulate research on dissociation within Wales among Welsh speakers. More broadly, at present there is a dearth of Welsh translated tests in both clinical and health psychology, 26,27,28 or indeed more widely within psychology.29,30,31 Further research may wish to provide a systematic review of available tests in psychology in the Welsh language, as well as providing translations of the more widely used psychometric tests.

*Christopher Alan Lewis, Professor of Psychology, Division of Psychology, Institute for Health, Medical Sciences and Society, Glyndŵr University, Plas Coch Campus, Mold Road, Wrexham, LL11 2AW, Wales, UK.

Email: ca.lewis@glyndwr.ac.uk

Martin J. Dorahy, Associate Professor of Psychology, Department of Psychology, University of Canterbury, Private Bag 4800, Christchurch 8140, New Zealand.

Julie Brake, Senior Lecturer in Welsh, Division of Education, Institute for Health, Medical Sciences and Society, Glyndŵr University, Plas Coch Campus, Mold Road, Wrexham, LL11 2AW, Wales, UK.

Mary Jane Lewis, Research Assistant, Division of Psychology, Institute for Health, Medical Sciences and Society, Glyndŵr University, Plas Coch Campus, Mold Road, Wrexham, LL11 2AW, Wales, UK.
References

1. Sanders S. The Perceptual Alteration Scale: A scale measuring dissociation. American Journal of Clinical Hypnosis 1986; 29: 95-102.

2. Riley KC. Measurement of dissociation. Journal of Nervous \& Mental Disease 1988; 176: 449-450.

3. Vanderlinden J, Van Dyck R, Vandereycken W, \& Vertomen $\mathrm{H}$. Dissociative experiences in the Netherlands and Belgium: A study with the Dissociative Questionnaire (DIS-Q). Dissociation 1993; 4: 180-184.

4. Harrison JA, Watson D. The Dissociative Processes Scale. Unpublished manuscript, Department of Psychology, University of lowa, lowa City, 1992

5. Briere J. Multiscale Dissociation Inventory. Odessa, FL: Psychological Assessment Resources, 2002.

6. Putnam FW, Helmers K, Trickett PK. Development, reliability, and validity of a child dissociation scale. Child Abuse \& Neglect 1993; 17: 731-741

7. Bernstein EM, Putnam FW. Development, reliability, and validity of a dissociation scale. Journal of Nervous \& Mental Disease 1986; 174: 727-735.

8. Carlson EB. Trauma assessment: A clinician's guide. New York: Guilford Press, 1997.

9. Armstrong JG, Putnam FW, Carlson EB, Libero DZ, Smith SR. Development and validation of a measure of adolescent dissociation: The Adolescent Dissociative Experiences Scale. Journal of Nervous \& Mental Disease 1997; 185: 491-497.

10. Lewis CA, Dorahy MJ, O'Rawe B, O'Rawe A. The Dissociative Experiences Scale: Replacement items for use with the visually impaired. Irish Journal of Psychological Medicine 2006; 23: 121-122 (Letter).

11. Lewis CA, Dorahy MJ, Lewis MJ, Baker SA. The Dissociative Experiences Scale: Replacement items for use with the profoundly deaf. Irish Journal of Psychological Medicine 2010; 27: 102 (Letter).

12. Carlson EB. Studying the interaction between physical and psychological states with the Dissociative Experiences Scale. In D. Spiegel (Ed.), Dissociation: Culture, mind, and body (pp. 41-58). Washington, DC: American Psychiatric Press, 1994.

13. Ensink BJ, Van Otterloo D. A validation study of the DES in the Netherlands. Dissociation 1989; 2: 221-223.

14. Yargic LI, Tutkun H, Sar V. Reliability and validity of the Turkish version of the Dissociative Experiences Scale. Dissociation 1995; 8: 10-13.

15. Umesue M, Matsuo T, Iwata N, Tashiro N. Dissociative disorders in Japan: A pilot study with the Dissociative Experiences Scale and a semi-structured interview. Dissociation 1996; 9: 182-189.

16. Spitzer C, Freyberger HJ, Stieglitz RD, Carlson EB, Kuhn G, Magdeburg N, Kessler C. Adaptation and psychometric properties of the German version of the Dissociative Experiences Scale. Journal of Traumatic Stress 1998; 11: 799-809.

17. Darves-Bornoz JM, Degiovanni A, Gaillard P. Validation of a French version of the Dissociative Experiences Scale in a rape victim population. Canadian Journal of Psychiatry 1999; 44: 271-275.

18. Somer E, Dolgin M, Saadon M. Validation of the Hebrew Version of the Dissociative Experiences Scale (H-DES) in Israel. Journal of Trauma \& Dissociation 2001; 2: 53-65.

19. Lipsanen T, Saarijärvi S, Lauerma H. The Finnish version of the Dissociative Experiences Scale-II (DES-II) and psychiatric distress. Nordic Journal of Psychiatry 2003; 57: 17-22.

20. Espírito Santo H, Abreu JLP. Portuguese validation of the Dissociative Experiences Scale (DES). Journal of Trauma \& Dissociation 2009; 10: 169-182.

21. Dobson R. Doctors in Wales should learn Welsh. British Medical Journal 1996; 313: 444.

22. Hughes L, Brookes C, Cocker C, John DN, Jones AT, 
Table 1 The 28 items of the Welsh translation of the DES

G P D Mae'r cwestiynau hyn yn disgrifio profiadau y mae'n bosib ichi eu cael yn eich bywyd bob dydd. Dylai eich ateb ddangos pa mor aml y mae'r profiadau'n digwydd ichi pan NA FYDDWCH dan ddylanwad alcohol neu gyffuriau. RHOWCH GYLCH O GWMPAS rhif rhwng 0\% i 100\% i nodi'r ganran o'r amser y mae hyn yn digwydd ichi. Os yw'n digwydd 45\% o'r amser, rhowch gylch o gwmpas $40 \%$ a $50 \%$.

Dyddiad

Oedran

Rhyw: G

B

1. Mae rhai pobl yn cael y profiad o yrru neu o deithio mewn car neu ar fws neu drên tanddaearol ac yn sylweddoli yn sydyn nad ydynt yn cofio'r hyn sydd wedi digwydd yn ystod yr holl daith neu am ran o'r daith.

$\begin{array}{llllllllllll}\text { (BYTH) } & 0 \% & 10 & 20 & 30 & 40 & 50 & 60 & 70 & 80 & 90 & 100\end{array}$

2. Mae rhai pobl yn gwrando ar rywun yn siarad ac yn sylweddoli'n sydyn na chlywsant ran neu'r cwbl o'r hyn a gafodd ei ddweud.

$\begin{array}{llllllllllll}\text { (BYTH) } & 0 \% & 10 & 20 & 30 & 40 & 50 & 60 & 70 & 80 & 90 & 100 \\ \text { (BOB TRO) }\end{array}$

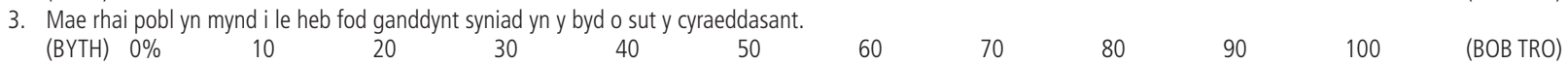

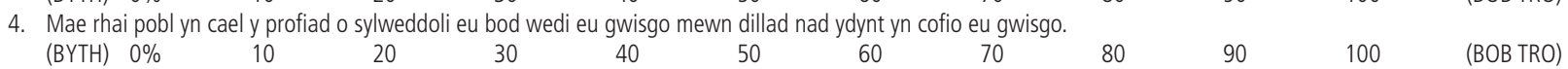

5. Mae rhai pobl yn cael y profiad o gael hyd i bethau newydd ymhlith eu heiddo nad ydynt yn cofio eu prynu.

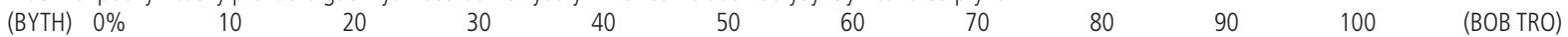

6. Mae rhai pobl weithiau'n cael pobl yn dod atynt nad ydynt yn eu hadnabod sy'n galw enw arall arnynt neu'n mynnu eu bod wedi cyfarfod â nhw o'r blaen.

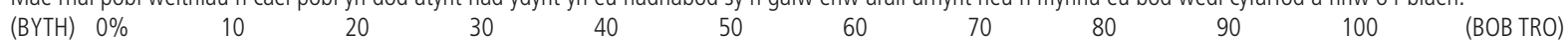

7. Mae rhai pobl weithiau'n cael y profiad o deimlo eu bod yn sefyll yn eu hymyl eu hunain neu'n eu gwylio eu hunain yn gwneud rhywbeth a byddant yn eu gweld eu hunain fel petaent yn edrych ar rywun arall.

$\begin{array}{llllllllllll}\text { (BYTH) } & 0 \% & 10 & 20 & 30 & 40 & 50 & 60 & 70 & 80 & 90 & 100\end{array}$

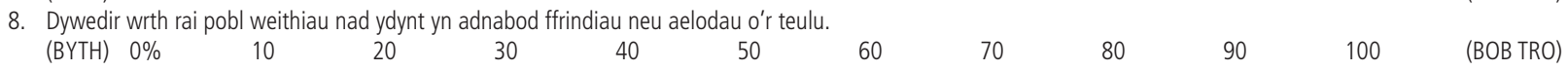

9. Mae rhai pobl yn methu â chofio rhai digwyddiadau pwysig yn eu bywydau (er enghraifft, priodas neu seremoni graddio).

$\begin{array}{llllllllllll}\text { (BYTH) } & 0 \% & 10 & 20 & 30 & 40 & 50 & 60 & 70 & 80 & 90 & 100\end{array}$

10. Mae rhai pobl yn cael eu cyhuddo o ddweud celwydd pan nad ydynt yn meddwl eu bod wedi dweud celwydd.

$\begin{array}{llllllllllll}\text { (BYTH) } & 0 \% & 10 & 20 & 30 & 40 & 50 & 60 & 70 & 80 & 90 & 100\end{array}$

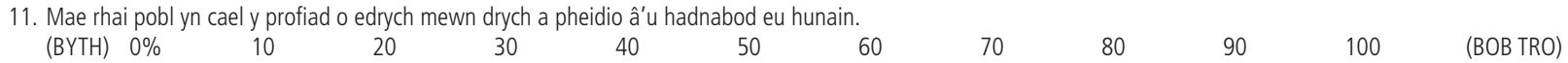

12. Mae rhai pobl yn cael y profiad o deimlo nad yw pobl a gwrthrychau eraill a'r byd o'u cwmpas yn real.

$\begin{array}{lllllllllllll}(\text { BYTH) } & 0 \% & 10 & 20 & 30 & 40 & 50 & 60 & 70 & 80 & 90 & 100 & \text { (BOB TRO) }\end{array}$

13. Mae rhai pobl yn cael y profiad o deimlo nad yw eu cyrff yn rhan ohonynt.

$\begin{array}{llllllllllll}(\text { (BYTH) } & 0 \% & 10 & 20 & 30 & 40 & 50 & 60 & 70 & 80 & 90 & 100\end{array}$

14. Mae rhai pobl yn cael y profiad weithiau o gofio digwyddiad a ddigwyddodd yn y gorffennol mor fyw maent yn teimlo fel petaent yn ail-fyw'r digwyddiad.

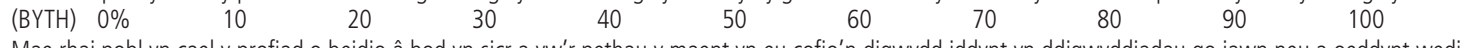

15. Mae rhai pobl yn cael y profiad o beidio â bod yn sicr a yw'r pethau y maent yn eu cofio'n digwydd iddynt yn ddigwyddiadau go iawn neu a oeddynt wedi

breuddwydio amdanynt

$\begin{array}{lllllllllll}\text { (BYTH) } & 0 \% & 10 & 20 & 30 & 40 & 50 & 60 & 70 & 80 & 90\end{array}$

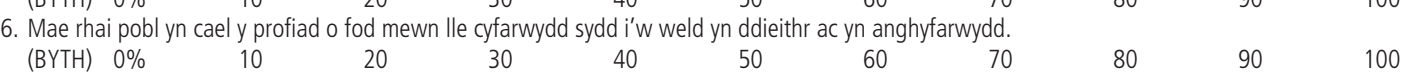

17. Pan fydd rhai pobl yn gwylio rhaglen deledu neu ffilm maent yn ymgolli gymaint yn y stori nid ydynt yn gwybod beth arall sy'n digwydd o'u cwmpas.

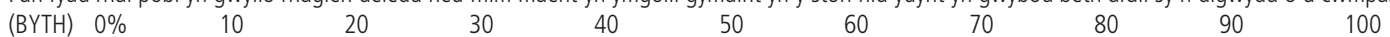

18. Mae rhai pobl yn ymgolli gymaint mewn ffantasi neu freuddwyd liw dydd mae fel petai'n digwydd iddynt yn go-iawn.

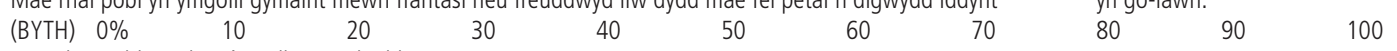

19. Mae rhai pobl weithiau'n gallu anwybyddu poen.

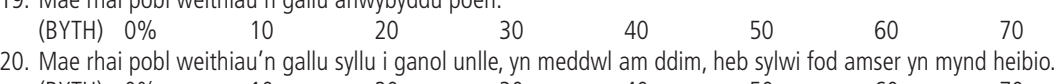
(BYTH) 0\%
$10 \quad 20 \quad 30$
$40 \quad 50 \quad 60$

80

$90 \quad 100$

(BOB TRO)

1. Mae rhai pobl weithiau'n siarad â'u hunain yn uchel pan fyddant ar eu pennau eu hunain.

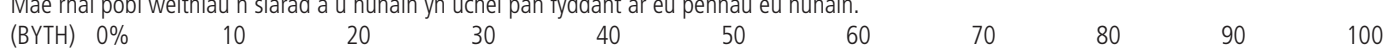

22. Mae rhai pobl yn ymddwyn mor wahanol mewn un sefyllfa o'i chymharu â sefyllfa arall maent yn teimlo bron petaent yn ddau berson gwahanol.

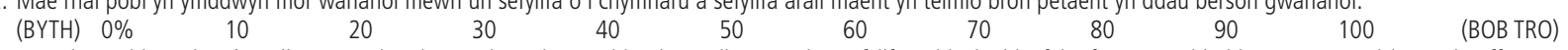

23. Mae rhai pobl weithiau'n gallu gwneud pethau yn hynod o rwydd a digymell mewn rhai sefyllfaoedd y byddai fel arfer yn anodd iddynt eu gwneud (er enghraifft, chwaraeon, gwaith, sefyllfaoedd cymdeithasol, etc.). (BYTH) $0 \%$
$20 \quad 30$
$\begin{array}{llll}40 & 50 & 60 & 70\end{array}$
$80 \quad 90 \quad 100 \quad$ (BOB TRO)

24. Mae rhai pobl yn sylwi nad ydynt yn gallu cofio a ydynt wedi gwneud rhywbeth neu dim ond wedi meddwl am ei wneud (er enghraifft, peidio â gwybod a ydynt newydd bostio llythyr neu dim ond wedi meddwl am ei bostio).
(BYTH) 0\%
$\begin{array}{llll}10 & 20 & 30 & 40\end{array}$
$\begin{array}{llll}40 & 50 & 60 & 70\end{array}$
$80 \quad 90$
100
(BOB TRO)

$\begin{array}{lllllllllll}\text { (BYTH) } & 0 \% & 10 & 20 & 30 & 40 & 50 & 60 & 70 & 80 & 90\end{array}$

26. Mae rhai pobl weithiau'n cael hyd i waith ysgrifenedig, lluniau, neu nodiadau ymhlith eu heiddo y mae'n rhaid mai nhw sydd wedi eu gwneud ond eu bod yn methu â chofio eu gwneud.
(BYTH) $0 \% \quad 10$

27. Mae rhai pobl weithiau'n $20 \quad 30$

(BYTH)

28. Mae rhai pobl weithiau'n teimlo eu bod yn edrych ar y byd drwy niwl fel bod pobl a gwrthrychau'n ymddangos yn bell i ffwrdd neu'n aneglur.
(BYTH) $0 \%$
10
20
30
$40 \quad 50$
60
$70 \quad 80$
$90 \quad 100$

(BOB TRO)

Longley M. The role of the Welsh language in community pharmacy service provision in Wales. London: The Pharmacy Practice Research Trust, 2008.

23. Madoc-Jones I. Linguistic sensitivity, indigenous peoples and the mental health system in Wales. International Journal of Mental Health Nursing 2004; 13: 216-224.

24. Misell A. Welsh in the Health Service: The scope, nature and adequacy of Welsh language provision in the National Health Service in Wales. Cardiff: Welsh Language Board, 2000.

25. Roberts G, Irvine F, Jones P, Spencer L, Baker C, Williams C. Report of a study of Welsh language awareness in healthcare provision in Wales. Cardiff: Welsh Assembly Government, 2005

26. Francis $L J$, Thomas EM. Welsh language adaptation of the short-form Junior Eysenck Personality Questionnaire Revised (JEPQR-S). Psychologist in Wales 2008; 21: 25-32.

27. Hills PR, Francis $L$, Thomas E. The psychometric properties and factor structure of a Welsh translation of the School Short Form of the Coopersmith Self-Esteem Inventory. Research in Education 2007; 78: 103-109.

28. Muntz R, Edwards RT, Tunnage B, Prys C, Roberts GW. Development of a Welsh language version of the EQ-5D Health-Related Quality of Life Measure. Stage one:
Translation. The Psychologist in Wales 2005; 18: 21-25.

29. Evans TE, Francis LJ. Measuring attitude toward Christianity through the medium of Welsh. In LJ Francis, WK Kay WS Campbell (Eds.), Research in religious education (pp. 279294). Leominster: Fowler Wright Books, 1996.

30. Lewis CA, Francis LJ. Reliability and validity of a Welsh translation of a short scale of attitude toward Christianity among 9-15 year olds. Irish Journal of Psychology 2002; 23: 101-108.

31. Wiliam U, Roberts G. The Welsh Children's Intelligence Scale. Windsor: NFER, 1972. 